\title{
Citra Perempuan Di Dalam Majalah Popular (Analisis Wacana Terhadap Artikel Di Majalah Popular Edisi Mei
}

\author{
2019) \\ Rosalin Febriyanti, Ahmad Junaedi, Nigar Pandrianto
rosalin.ferbiyanti@gmail.com,ahmadd@fikom.untar.ac.id, nigarp@fikom.untar.ac.id
}

Fakultas Ilmu Komunikasi Universitas Tarumanagara

\begin{abstract}
This study is entitled "Women's Image in Magazine Photos (Semiotic Analysis of Photos in Popular Magazine May 2019 Edition)". The object of this research is a photo in the May 2019 issue of Popular magazine. This study uses Rholand Barthes's semiotic analysis framework. The purpose of this research is to find out how the depiction of the objectification of women in the photo model of the May 2019 Popular Magazine and expose the myths contained in the photos. There is objectification in the sexual form which makes a woman's body an object to be observed, valued, and enjoyed by her sexual values. The myth that can be unearthed from the meaning of the sign in the photographs is the beauty myth that defines women's beauty in uniform criteria.
\end{abstract}

Keywords: roland barthes semiotics, feminism, objectivity

\begin{abstract}
Abstrak
Penelitian ini mengangkat tentang citra wanita dalam foto di majalah. Objek penelitian ini adalah foto di Majalah Popular Edisi Mei 2019. Kerangka analisis yang digunakan pada penelitian ini yaitu Analisis Semiotika Roland Barthes yang memiliki tujuan pencitraan perempuan dalam foto, serta menggali kebenaran tentang adanya pemaknaan tanda dalam foto-foto keanggunan wanita sesuai dengan porsi yang sama. Tujuan dari penelitian ini adalah untuk mengetahui bagaimana penggambaran objektifikasi perempuan dalam model foto di Majalah Popular dan memaparkan mitos-mitos yang terkandung dalam foto. Terdapat objektifikasi dalam bentuk seksual yang membuat tubuh wanita menjadi objek untuk diamati, dihargai, dan dinikmati oleh nilai-nilai seksualnya. Mitos yang dapat digali dari makna tanda dalam foto adalah mitos kecantikan yang mendefinisikan kecantikan wanita dalam kriteria seragam.
\end{abstract}

Kata Kunci: semiotika Roland Barthes, feminisme, objektivikasi

\section{Pendahuluan}

Seksualitas perempuan melalui kata-kata dan gambar, menunjukan posisi media dalam menyikapi erotisme dan pornografi. Sebagian media cetak menggunakan isu moralitas dan perendahan perempuan sebagai ungkapan ketidaksetujuan terhadap erotisme dan pornografi. Sedangkan media cetak yang lain menggunakan alasan kebebasan ekspresi sebagai basis atas ketidaksetujuan atas pelanggaran terhadap erotisme dan pornografi. Dalam kasus-kasus yang dekat dengan erotisme, kebanyakan media cetak utama (mainstream) membela dengan menggunakan alasan kebebasan berekspresi dan menentang segala bentuk sensor> Namun demikian, sebagian media menganggap terorisme tersebut sudah mengarah dan masuk dalam kategori 
pornografi. Media utama atau (mainstream media) adalah media-media yang menyajikan berita atau artikel politik, ekonomi dan kebudayaan dengan sifat selain normatif dan edukatif, juga menghindari eksploitasi seksual (Junaidi, 2002).

Objektifikasi tentang seluk beluk badan wanita dengan mudahnya menyebar luas melalui berbagai macam media. Baik itu media cetak ataupun sebagainya. Dengan berbagai jenis media yang ada, tentunya mempermudah akses bagi masyarakat. Dalam dunia media massa keindahan perempuan dan kekaguman lelaki terhadap perempuan merupakan sebuah kesatuan yang utuh dimana, dengan modal kecantikan yang menjadi bahan inspirasi yang tidak ada habisnya bagi para pekerjaan seni (Burgin, 2005).

Gerakan advokasi yang erat dengan wanita adalah feminis atau feminisme. Pada awalnya merupakan sebuah reaksi untuk memperjuangkan hak perempuan. Menurut Goodman dan Ritzer (2012), teori feminisme terpusat pada perempuan dalam tiga hal. Pertama, sasaran studinya adalah situasi dan pengalaman perempuan dalam masyarakat. Kedua, dalam proses penelitiannya perempuan dijadikan "sarana" sentral yang berarti mencoba melihat dunia luar dari sudut pandang perempuan terhadap dunia sosial. Ketiga, teori feminisme dikembangkan oleh para pemikir kritis dan aktivis atau pejuang demi kepentingan perempuan yang mencoba menciptakan kehidupan lebih baik dengan tujuan kemanusiaan. Feminisme eksistensialis membahas mengenai konstruksi sosial gender perempuan yang belum dapat mempunyai persamaan hak antara jenis yang berbeda, yang berkaitan dengan citra.

Menurut Syarifah (2006), objektifikasi terjadi, ketika seseorang, melalui saranasarana sosial direndahkan derajatnya, dijadikan benda atau komoditas, dibeli atau dijual. Memperlakukan seseorang layaknya barang tanpa mempertimbangkan martabat mereka menjadikan hal perkara atau pokok pikiran, sasaran, tujuan, pelengkap atau tujuan penderita.

Penelitian ini menggunakan Analisis Semiotika. Pengertian semiotika (Sobur, 2009) adalah suatu model ilmu pengetahuan sosial yang memahami dunia sebagai suatu unit dasar yang disebut dengan "tanda". Maka dari itu, semiotik memahami keberadaan dengan suatu tanda.

Gambar 1. Kerangka Konseptual

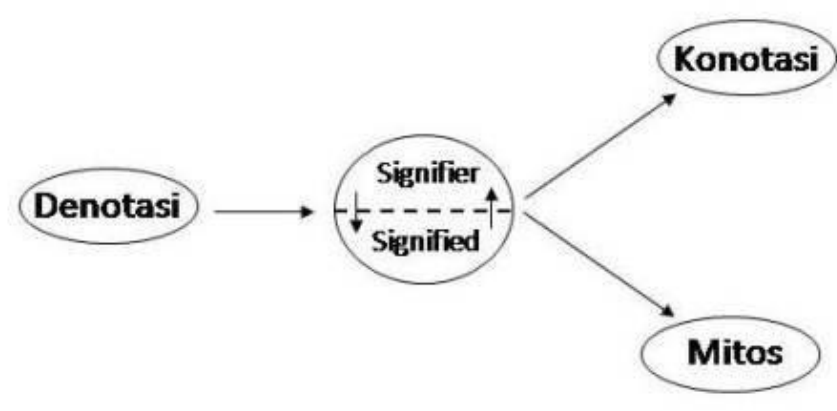

Sumber : dokumentasi pribadi

Pada kerangka pemikiran tersebut, analisis semiotika Roland Barthes signifikasi dua tahap, denotasi, konotasi dan mitos. 


\section{Metode Penelitian}

Metode penelitian yang digunakan dalam penelitian ini adalah kualitatif berparadigma kritis. Tujuan penelitian dengan paradigma kritis adalah untuk mengkritik hubungan sosial yang tersimpan dan bermaksud untuk menghilangkan keyakinan serta gagasan palsu yang beredar di masyarakat dan mengkritik sistem kekuasaan yang mendominasi satu kelompok.

Penelitian ini menggunakan metode penelitian kualitatif. Objek yang alamiah adalah objek yang berkembang apa adanya, tidak dimanipulasi oleh peneliti dan kehadiran peneliti tidak begitu mempengaruhi dinamika yang terjadi pada objek tersebut. Dalam penelitian kualitatif instrumennya adalah model dalam penelitian penulis. (Sugiyono, 2011).

\section{Hasil Temuan dan Diskusi}

Dari hasil Analisis Semiotika Roland Barthes yang terlihat pada foto dalam majalah, badan perempuan dijadikan sebagai suatu hal yang dapat dijual serta memenuhi hasrat pembaca. Dalam gambar tersebut badan perempuan dianggap sebagai komoditi yang dapat dijual dan bernilai bisnis, tidak semata hanya diri yang mempunyai jiwa. Standar ideal seorang wanita yaitu dengan aset kulit putih dan badan ramping. Menelusuri kebenaran kecantikan yang merebak di masyarakat, menjadikan perempuan memiliki nilai dalam dirinya yang dapat ditampilkan di khalayak.

Mitos kecantikan ditampilkan melalui berbagai media dan disuguhkan kepada masyarakat menyebabkan kaum perempuan menetapkan kualitas dirinya berdasarkan keindahan fisik yang ditampilkan di media massa tersebut. Akhirnya, perempuan terbiasa bercermin pada media massa dan membandingkan dirinya dengan artis-artis cantik di majalah atau televisi.

Mitos kecantikan berkaitan dengan tipe perempuan dalam feminisme eksistensialis. Seorang terobsesi untuk menyempurnakan wajah, tubuh dan pakaiannya. Kualitas diri narsisme ditentukan oleh penilaian fisiknya oleh masyarakat. Ia menganggap dirinya berharga jika dianggap cantik oleh masyarakat. Seorang narsisme seolah tidak mempunyai rasa percaya diri untuk menentukan definisi kecantikan bagi dirinya sendiri. Akibatnya, ia hanya menghabiskan waktunya untuk berdandan dan melupakan kegiatan-kegiatan yang bermanfaat untuk meningkatkan kualitas dirinya, misalnya menambah wawasan dan pengetahuannya bila dikaitkan dengan paham feminisme eksistensialis, perempuan dalam foto-foto tersebut. Biasanya merupakan kegiatan yang memiliki tujuan, kesenangan dan kepuasan dalam melaksanakannya. Kegiatan ini dilakukan berdasarkan pilihan dan pertimbangan untuk mencapai tujuan tertentu.

\section{Simpulan}

Seksualitas menempatkan tubuh perempuan sebagai perkara untuk diteliti dan dilihat hanya dari luarnya saja serta menjawab ketabuan yang dapat diungkapkan dari foto itu yaitu antic dari luar berkulit putih mulus tubuh langsung 


\section{Ucapan Terima Kasih}

Dalam proses penulisan skripsi ini, peneliti banyak sekali mendapatkan dukungan, bimbingan, bantuan, serta saran. Selain itu, penulis juga mengucapkan terima kasih kepada orang tua, keluarga, teman-teman serta semua pihak yang tidak dapat disebutkan satu persatu yang telah banyak mendukung penulis.

\section{Daftar pustaka}

Burgin, Burhan, (2005). Edisi Revisi, Pornomedia, Sosiologi Media, Konstruksi Eriyanto, Analisis Framing: Kontruksi, Ideologi, dan Politik Media, Lkis, Yogyakarta: 2002

Junaidi, Ahmad (2012). Porno! Feminisme, Seksualitas \& Pornografi Di Media, Jakarta: Kompas Gramedia

Moleong, J. Lexy (2006), Metode Penelitian Kualitatif, Bandung: Remaja Rosda Karya

Ritzar, J. Godman, (2012), Edisi Terbaru: Teori Sosiologi, Yogyakarta: Kreasi Wacana

Sobur, Alex (2004). Analisis Teks Media, Bandung: Remaja Rosda Karya

Sobur, Alex (2004). Semiotika Komunikasi, Bandung: Remaja Rosda Karya

Sosial Teknologi Telematika \& Perayaan Seks Di Media Massa, Jakarta: Prenda Media

Sugiyono, (2011), Metode Penelitian Kuantitatif, Kualitatif Dan R\&D. Bandung: Alfabeta

Sunarto, Hermawan, (2011), Mix Methodology Dalam Penelitian Komunikasi, Jakarta: ASPIKOM

Suryandaru, Sakti Yayan. (2002). Potret Kesadaran Gender Orang Media

Syarifah, (2006), Kebertubuhan Perempuan dalam Pornografi. Jakarta: Yayasan Kota

Tong, Rosemary Putnam, Feminist Tought : A More Comperhensive In troduction. West View Press. Colorado :1998

https://www.popular-world.com/

https://kbbi.web.id/ 